\title{
Preliminary comparative phytochemical screening and antioxidant activity of varieties Vaccinium corymbosum L. (Ericaceae) shoot' extracts
}

\author{
N. Y. Yavorska ${ }^{1}$, N. M. Vorobets ${ }^{1}$, Yu. T. Salyha ${ }^{2}$, O. I. Vishchur ${ }^{2}$ \\ vishchur_oleg@ukr.net \\ ${ }^{1}$ Danylo Halytsky Lviv National Medical University, \\ 69 Pekarska str., Lviv, 79010, Ukraine \\ ${ }^{2}$ Institute of Animal Biology NAAS, \\ 38 Vasyl Stus str., Lviv, 79034, Ukraine
}

Nowadays, the created varieties of Vaccinium corymbosum L. (Ericaceae) are widespread in different regions of all continents with a suitable climate. Until now, mainly the fruits of these plants have been used, and the vegetative aerial part that remains when pruning the bushes has not been employed. Meanwhile, shoots of other species of Ericaceae have long been used as raw materials for the needs of pharmacy, medicine and veterinary medicine. Phytochemical screening methods were used for the detection of various phytochemicals in shoots of three varieties $V$. corymbosum introduced in Ukraine by qualitative chemical tests to give a general idea regarding the nature of constituents present in plant material, especially with antioxidant activity. Furthermore, the content of extractives was determined in the obtained extracts and their antioxidant activity by determining the total antioxidant capacity using the DPPH radical scavenging method on various stages of plant development. Phytochemical screening on the shoots of three $V$. corymbosum varieties (Bluejay, Bluecrop, Elliott) showed the presence of carbohydrates, reducing sugars, phenols, flavonoids, tannins, phlobatannins, hydroquinone and arbutin that exhibit antioxidant properties; the extractive value depends on the solvent and stage of plant development. Bluejay in aqueous extracts had the greatest amount of extractives during flowering and at the beginning of the winter period; in Bluecrop it was during fruiting and at the beginning of the winter period; and in Elliott - at the beginning of the winter period. Thus, we can assume the prospects of their study on antimicrobial properties, anti-inflammatory, anti-diabetic, as well as a feed additive for animal feed.

Key words: Vaccinium corymbosum varieties, extractives, screening of soluble compounds, antioxidant activity

The introduction of new sources of raw materials for the pharmaceutical, veterinary, medical industry, as well as new food products is preceded by their thorough and comprehensive study. Vaccinium corymbosum L. (Ericaceae) is an indigenous plant species of the American continent, the varieties of which are now ubiquitous in Europe and in Ukraine because of the tasty and healthy fruits. In recent years, we drew attention to its vegetative aboveground part, as bushes of $V$. corymbosum need trimming, and cut parts are not used. Meanwhile, the above-ground part of plants growing in nature is actively eaten by animals and birds and is used by local residents for medicinal purposes. The above information suggests the possibility of using the aboveground part of plants as animal feed and/or medicinal plant raw materials for the creation of drugs for the treatment of humans and/or animals. Before using plants as raw materials, they should be tested for the content of different groups of biologically active substances (BAS). Generally, the activities of crude extracts derived from plants, may change based on changes in chemical composition, which, in turn, may be due to grades, location, environmental conditions and physiological phase harvested plant material. Therefore, it is important to thoroughly investigate the plant varieties that are available for use on the content of BAS in different physiological stages of development and in certain climates they grow. The chemical composition of several Vaccinium species has identified that phenolic compounds apparently determine their pharmacological value [14]. Although, many other compounds of the plants of Ericaceae have important physiological and therapeutic effects on the human body and animals.

This stage of research was devoted the determination of the content of extractive substances, the presence of a wider spectrum of BAS, as well as the determination of the antioxidant activity (AOA) of aqueous and ethanol-aqueous shoot extracts of three $V$. corymbosum varieties. 


\section{Materials and Methods}

\section{Collection and authentication of plant material}

Samples of shoots of highbush blueberry (Vaccinium corymbosum L.) variety Bluecrop, Bluejay and Elliott were collected directly from the manufacturer LLC "Berry Partner" at the experimental exhibition site in the village of Sokilnyky (Lviv region, Ukraine) during 2017-2019, in various phenological stages: during flowering (I), fruiting (II), after fruiting (III), the period of preparing (which precedes) for winter dormancy (IV) (in May, July, October, December, respectively).

The growth stages were determined according to the biologist of Michigan State University [7]. Shoots were dried in the shade at room temperature $\left(22-24^{\circ} \mathrm{C}\right)$ and crushed in a knife mill.

The resulting powders of air-dried shoots were collected, passed through a sieve with a mesh size of $2 \mathrm{~mm}$ and used for extraction.

\section{Reagents and standards}

Only analytical chemicals purchased from the company Sfera Sim (Lviv, Ukraine) were used in the studies, and the DPPH radical (1,1-diphenyl-2-picrylhydrazyl) was purchased from Sigma Aldrich Chemical.

\section{Preparation of the extracts}

Aqueous extracts of shoots of highbush blueberry cv. Bluecrop, Bluejay and Elliott were performed by suspended $2 \mathrm{~g}$ of material in $20 \mathrm{ml}$ of distilled water under reflux conditions in a boiling water bath for 30 minutes. Aqueous ethanol extracts $(20 \%, 30 \%, 40 \%, 50 \%, 60 \%$, $70 \%, 80 \%, 96 \%$ ) of air-dry shoots were prepared by maceration methods according to State Pharmacopoea of Ukraine (1:10 / weight: volume /g:ml, 14 days in darkness at $\left.25^{\circ} \mathrm{C}\right)[11,12]$. After completing the extraction process, each $V$. corymbosum extract was filtered through Whatman No.1 filter paper in order to obtain a clear crude extract solution. Subsequently, this crude extract was subjected to antioxidant assay and value of extractive matter and phytochemical screening.

\section{Estimation of extractive value}

Investigation of the weight percentage yield of the extracts have been done because according to WHO and Pharmacopoeia of Ukraine, and the determination of water soluble and alcohol soluble extractives is used as a means of evaluating crude drugs which are not readily estimated by other means. The yield of each extract expressed on the dry weight basis of extract was calculated from the following equation:

$$
\text { Extraction yield }(\% \text { yield or } \mathrm{g} / 100 \mathrm{~g})=\frac{(\mathrm{W} 1 \times 100)}{\mathrm{W} 2}
$$

where $\mathrm{W} 1$ is the weight of the extract resudue obtained after solvent removal;

W2 is the weight of the plant raw material taken for extract preparation.

Extractive value of Vaccinium corymbosum shoots extract in terms of dry raw materials is, mean \pm SEM $(\% \mathrm{w} / \mathrm{w})$.

\section{Phytochemical analysis}

The phytochemical screening of $V$. corymbosum shoots included detection in aqueous and aqueous etha- nol extracts of carbohydrates, reducing sugars, phenolic compounds, tannins, phlobatannins, flavonoids, hydroquinone and arbutin, and performed using standard procedures with slight modifications [5-6, 8-9, 11-13].

Detection of carbohydrates (Molisch's Test) [8, 13]: Extracts $(5 \mathrm{ml})$ were treated with 2 drops of alcoholic a-naphthol solution in test solutions. Formation of red precipitate indicates the presence of sugars.

Detection of reducing sugars (Fehling's test) [13]: The extract was added to boiling Fehling's solution ( $A$ and $B$ ) in a test tube and boiled for five minutes. The solution was observed in a colour reaction - first yellow and then a brick red if reducing sugars are present.

Detection of phenols [8]: First method, Ferric Chloride Test: Extracts (2 ml) were treated with 3-4 drops of ferric chloride solution (5\%). Formation of bluish black colour indicates the presence of phenols. Second method, $2 \mathrm{ml}$ extract after adding $3 \mathrm{ml}$ of lead acetate (10\%) is considered as positive if white precipitate appears.

Detection of flavonoids [8, 11, 12]: First method, dilute ammonia $(5 \mathrm{ml})$ was added to a portion of an aqueous or ethanolic extract. A concentrated sulphuric acid $(1 \mathrm{ml})$ was added. Yellow colouration that disappears on standing indicates the presence of flavonoids. Second method, (Alkaline Reagent Test): Extracts were treated with few drops of sodium hydroxide solution (10\%). Formation of intense yellow colour, which becomes colourless on the addition of dilute acid, indicates the presence of flavonoids. Third method, a few drops of $1 \%$ aluminium solution were added to a portion of the extract. Yellow colouration indicates the presence of flavonoids.

Test for tannins [11-13]: First method, a little of $1 \%$ gelatine in water containing $10 \%$ sodium chloride was added to the extract. Formation of white precipitate indicates the presence of tannins. Second method, a few drops of $0.1 \%$ ferric chloride was added to the extract and observed for brownish green or blue-black colouration, tannins are present. Third method, 2-3 $\mathrm{ml}$ of extract was added to $10 \%$ lead acetic solution; white precipitate indicates the presence of tannins. Fourth method, two drops of vanillin reagent containing $1 \%(\mathrm{w} / \mathrm{v})$ vanillin in ethanol were added to the sample. When completely absorbed, two drops of $\mathrm{HCl}$ were added. The appearance of red colour indicates the presence of condensed tannins. Fifth method, $1 \mathrm{ml}$ of extract was added to 2-3 drops of iron-ammonium alum; the appearance of turbidity in black and blue colours indicate the presence of hydrolysed tannins, black and green colours indicate the presence of condensed tannins.

Test for phlobatannins [9]: Two millilitres $(2 \mathrm{ml})$ of the aqueous solution of the extract were added into $5 \mathrm{ml}$ dilute $(1 \%) \mathrm{HCl}$. Red precipitate shows the presence of phlobatanins.

Detection of Hydroquinone [5, 13]: First method, Appearance of colours from yellow green to golden when hydroquinone is heated to $100^{\circ} \mathrm{C}$ with sodium nitrite and diluted sulfuric acid, when sodium hydroxide is added, the colour changes to yellow brown. Second method, to $1 \mathrm{ml}$ of extract was added dropwise nitric acid, the appearance of dark red coloration, gradually turning into yellow color determines the presence of hydroquinone. Third method, hydroquinone reacts with bromine water to form white precipitate.

Detection of arbutin [13]: First method, add a crystal of ferrous iron to $1 \mathrm{ml}$ of extract and arbutin with ferric 
chloride gives blue colour (the most specific reaction). Second method, arbutin with an alcoholic solution of the $\mathrm{FeSO}_{4}$ gives yellow green coloration. Third method, to $1 \mathrm{ml}$ of extract was added drop by drop $1 \mathrm{ml}$ of $10 \%$ sodium phosphoromolybdic acid in $\mathrm{HCl}$ and dark blue precipitate indicates the presence of arbutin.

Determination of antioxidant activity [1, 6]: The antioxidant activity (radical scavenging activity) of the extracts was measured by using the 2,2-diphenyl-1-picrylhydrazyl radical (DPPH•) according to slightly modified method previously described. $2 \mathrm{ml}$ of the extract was placed in a test tube and added follow by $2 \mathrm{ml}$ of $1 \mathrm{mM}$ DPPH in ethanol. The mixture was shaken and then left to stand for $30 \mathrm{~min}$ in dark. The absorbance of the resulting mixture after the reaction was taken at $517 \mathrm{~nm}$ using spectrophotometer СФ-46 (ЛОМО). A blank solution was prepared containing the same amount of ethanol and 2,2-Diphenyl-1-picryl hydrazyl (DPPH). The reading was converted to percentage antioxidant activity (\% AOA) using the following formula:

$$
\% A O A=\{[A b-A a] \div A b\} \times 100,
$$

where $A b$ is the absorption of the blank sample,

$A a$ is the absorption of the sample (extract).

To determinate the $50 \%$ of inhibitory concentration (IC50), serial dilutions of extracts and/or phenolic standards were used to measure the scavenging of DPPH • radical as a function of serial dilution. Each determination was performed in triplicate and repeated at least three times and using a linear regression to calculate the concentration to scavenge the $50 \%$ of DPPH .

Ascorbic acid was used as the antioxidant standard at concentrations of $0.0125,0.025,0.050,0.100,0.200$; 0.400 and $0.800 \mathrm{mg} / \mathrm{ml}$. The $\mathrm{IC}_{50}$ value of the extract was compared with that of the ascorbic acid.

\section{Results and Discussion}

An important characteristic and the main stage in obtaining phytopreparations is the extraction of a complex of compounds with medicinal plant raw materials. Determining the optimal solvent (extractant) of the dry material had been done with water and aqueous ethanol $(A E)$ of different concentrations, and the weight percentage yield of the crude extracts of title plants are given in table 1. The results show that their content depends on the solvent and stage of the development. Some differences were also revealed among the studied varieties.

Bluejay in aqueous extracts had the greatest quantity of extractives during flowering and at the beginning of the winter period; in Bluecrop it was during fruiting and at the beginning of the winter period; and in Elliott - at the beginning of the winter period (table 1). Water was a good extractant as well as ethanol-water solutions. In general, a comparison of the level of extractives in the obtained extracts indicates that $60 \%$ ethanol is the best solvent; therefore, phytochemical screening was carried out with aqueous and $60 \%$ ethanol extracts.

The phytochemical tests (total water-soluble and waterethanol-soluble compounds) carried on the shoots of three varieties $V$. corymbosum shoot extract showed the presence of different types of primary and secondary
Table 1. Extractive value of Vaccinium corymbosum shoots in terms of dry raw materials, \% w/w (mean \pm SEM, $n=3$ )

\begin{tabular}{|c|c|c|c|c|}
\hline $\begin{array}{l}\text { Samples } \\
\text { (solvent) }\end{array}$ & I & II & III & IV \\
\hline \multicolumn{5}{|c|}{ Bluejay } \\
\hline $\mathrm{H}_{2} \mathrm{O}$ & $21.40 \pm 2.03$ & $20.52 \pm 1.01$ & $19.78 \pm 1.56$ & $23.06 \pm 1.50$ \\
\hline $20 \% \mathrm{AE}$ & $20.72 \pm 3.65$ & $26.47 \pm 1.76$ & $16.14 \pm 2.04$ & $20.47 \pm 1.21$ \\
\hline $30 \% \mathrm{AE}$ & $30.11 \pm 1.68$ & $22.46 \pm 1.03$ & $22.63 \pm 2.38$ & $21.05 \pm 1.05$ \\
\hline $40 \% \mathrm{AE}$ & $26.57 \pm 1.42$ & $22.08 \pm 3.08$ & $21.74 \pm 3.20$ & $21.49 \pm 1.59$ \\
\hline $50 \% \mathrm{AE}$ & $24.93 \pm 4.38$ & $15.76 \pm 1.98$ & $21.57 \pm 1.41$ & $21.36 \pm 1.83$ \\
\hline $60 \% \mathrm{AE}$ & $32.84 \pm 1.04$ & $24.18 \pm 1.34$ & $28.13 \pm 1.96$ & $26.19 \pm 1.20$ \\
\hline $70 \% \mathrm{AE}$ & $22.50 \pm 1.34$ & $24.12 \pm 1.91$ & $22.77 \pm 1.27$ & $27.33 \pm 1.16$ \\
\hline $80 \% \mathrm{AE}$ & $22.99 \pm 1.46$ & $23.49 \pm 1.25$ & $12.51 \pm 3.04$ & $22.95 \pm 2.39$ \\
\hline $96 \%$ AE & $24.69 \pm 3.45$ & $25.17 \pm 1.73$ & $20.68 \pm 1.28$ & $25.40 \pm 1.76$ \\
\hline \multicolumn{5}{|c|}{ Bluecrop } \\
\hline $\mathrm{H}_{2} \mathrm{O}$ & $20.87 \pm 1.44$ & $30.13 \pm 3.24$ & $22.40 \pm 4.04$ & $25.15 \pm 4.87$ \\
\hline $20 \% \mathrm{AE}$ & $20.76 \pm 2.35$ & $15.86 \pm 3.35$ & $25.39 \pm 4.08$ & $26.01 \pm 2.94$ \\
\hline $30 \% \mathrm{AE}$ & $27.06 \pm 5.76$ & $25.18 \pm 4.85$ & $20.15 \pm 4.87$ & $20.71 \pm 2.67$ \\
\hline $40 \% \mathrm{AE}$ & $23.78 \pm 2.54$ & $19.85 \pm 2.42$ & $21.55 \pm 4.18$ & $22.74 \pm 5.71$ \\
\hline $50 \% \mathrm{AE}$ & $26.18 \pm 4.24$ & $21.78 \pm 4.57$ & $24.37 \pm 5.15$ & $23.11 \pm 3.84$ \\
\hline $60 \% \mathrm{AE}$ & $25.12 \pm 3.97$ & $24.51 \pm 3.35$ & $22.76 \pm 3.10$ & $22.59 \pm 2.46$ \\
\hline $70 \% \mathrm{AE}$ & $23.34 \pm 3.67$ & $22.25 \pm 3.51$ & $16.63 \pm 1.73$ & $23.84 \pm 3.89$ \\
\hline $80 \% \mathrm{AE}$ & $23.67 \pm 1.51$ & $25.72 \pm 3.86$ & $23.53 \pm 1.21$ & $35.38 \pm 3.99$ \\
\hline $96 \% \mathrm{AE}$ & $24.67 \pm 2.34$ & $30.11 \pm 4.88$ & $24.28 \pm 2.77$ & $20.58 \pm 3.69$ \\
\hline \multicolumn{5}{|c|}{ Elliott } \\
\hline $\mathrm{H}_{2} \mathrm{O}$ & $21.79 \pm 3.75$ & $16.30 \pm 2.94$ & $20.67 \pm 4.10$ & $29.37 \pm 5.79$ \\
\hline $20 \% \mathrm{AE}$ & $23.67 \pm 5.83$ & $27.80 \pm 3.52$ & $21.55 \pm 1.91$ & $19.16 \pm 3.85$ \\
\hline $30 \% \mathrm{AE}$ & $27.11 \pm 3.72$ & $28.88 \pm 5.49$ & $21.52 \pm 1.44$ & $27.74 \pm 6.59$ \\
\hline $40 \% \mathrm{AE}$ & $24.75 \pm 4.62$ & $26.95 \pm 4.16$ & $16.96 \pm 4.23$ & $21.53 \pm 3.21$ \\
\hline $50 \% \mathrm{AE}$ & $24.69 \pm 4.53$ & $24.11 \pm 4.46$ & $21.93 \pm 5.02$ & $24.35 \pm 4.60$ \\
\hline $60 \% \mathrm{AE}$ & $15.02 \pm 2.97$ & $23.74 \pm 3.21$ & $22.98 \pm 2.49$ & $22.59 \pm 5.79$ \\
\hline $70 \% \mathrm{AE}$ & $23.35 \pm 4.37$ & $26.48 \pm 2.45$ & $17.49 \pm 2.40$ & $22.86 \pm 3.60$ \\
\hline $80 \% \mathrm{AE}$ & $20.88 \pm 2.85$ & $25.23 \pm 3.86$ & $22.87 \pm 1.13$ & $24.19 \pm 5.36$ \\
\hline $96 \% \mathrm{AE}$ & $14.25 \pm 1.74$ & $27.18 \pm 3.65$ & $24.17 \pm 4.33$ & $25.35 \pm 2.44$ \\
\hline
\end{tabular}

Note. AE - Aqueous ethanol; I, II, III, IV — stages of flowering, fruiting, after fruiting, preparing for winter dormancy, respectively.

metabolites (table 2). The tests performed on the shoot extracts of Bluejay, Bluecrop, and Elliott varieties showed the presence of carbohydrates, reducing sugars, phenols, flavonoids, tannins, phlobatannins. All of them are involved in important biological activities. Polyphenols can have favourable effects on the incidence of cancers, diabetes (type 2) and chronic diseases, including neurodegenerative [2]; their dietary consumption has shown to be inversely associated with morbidity and mortality by cardioand cerebrovascular diseases (atherosclerosis, brain 
Table 2. Phytochemical constituents of crude extracts of Vaccinium corymbosum varieties shoots

\begin{tabular}{|c|c|c|c|c|c|c|c|}
\hline \multirow[b]{2}{*}{ Detection of: } & \multirow[b]{2}{*}{ Test } & \multicolumn{2}{|c|}{ Bluejay } & \multicolumn{2}{|c|}{ Bluecrop } & \multicolumn{2}{|c|}{ Elliott } \\
\hline & & $\begin{array}{l}\text { Aqueous } \\
\text { extract }\end{array}$ & $60 \% \mathrm{AE}$ & $\begin{array}{l}\text { Aqueous } \\
\text { extract }\end{array}$ & $60 \% \mathrm{AE}$ & $\begin{array}{l}\text { Aqueous } \\
\text { extracts }\end{array}$ & $60 \% \mathrm{AE}$ \\
\hline carbohydrates & Molisch's test & + & + & + & + & + & + \\
\hline reducing sugars & Fehling's test & + & + & + & + & + & + \\
\hline \multirow{2}{*}{ phenols } & with Ferric Chloride (5\%) & + & + & + & + & + & + \\
\hline & with lead acetate $(10 \%)$ & + & + & + & + & + & + \\
\hline \multirow{3}{*}{ flavonoids } & with dilute ammonia and conc. $\mathrm{H}_{2} \mathrm{SO}_{4}$ & + & + & + & + & + & + \\
\hline & with $10 \%$ sodium hydroxide solution & + & + & + & + & + & + \\
\hline & with $1 \%$ aluminium solution & + & + & + & + & + & + \\
\hline \multirow{5}{*}{ tannins } & with $1 \%$ gelatin & ++ & +++ & ++ & +++ & ++ & ++ \\
\hline & with $0.1 \%$ ferric chloride & ++ & ++ & ++ & ++ & ++ & ++ \\
\hline & with iron-ammonium alum & +++ & +++ & +++ & ++ & +++ & +++ \\
\hline & with $10 \%$ lead acetic & ++ & +++ & +++ & +++ & ++ & ++ \\
\hline & with $1 \%(\mathrm{w} / \mathrm{v})$ vanillin in ethanol & + & + & + & + & + & + \\
\hline phlobatannins & With $1 \% \mathrm{HCl}$ & ++ & +++ & ++ & ++ & + & + \\
\hline \multirow{3}{*}{ hydroquinone } & $\begin{array}{l}\text { heated to } 100^{\circ} \mathrm{C} \text { with sodium nitrite } \\
\text { and diluted sulfuric acid }\end{array}$ & + & + & + & ++ & + & ++ \\
\hline & with nitric acid & - & ++ & - & + & - & ++ \\
\hline & with bromine water & ++ & ++ & + & ++ & ++ & +++ \\
\hline \multirow{3}{*}{ arbutin } & with ferric chloride & + & + & + & + & + & + \\
\hline & with $\mathrm{FeSO}_{4}$ & + & + & + & + & + & + \\
\hline & $\begin{array}{l}\text { with } 10 \% \text { sodium phosphoromolybdic } \\
\text { acid in } \mathrm{HCl} \text { and } 5 \% \mathrm{NH}_{4} \mathrm{OH}\end{array}$ & + & ++ & ++ & ++ & + & +++ \\
\hline
\end{tabular}

Note. AE - Aqueous ethanol; $(+)=$ Present, $(-)=$ Absent.

dysfunction, stroke) [15]. Advances in investigation of polyphenols bioavailability and metabolism, in the mechanisms of action, and in the evidence of health effects on animal models and humans have been reported [16].

The qualitative analysis of hydroquinone and its' derivative arbutin in the shoots of three highbush blueberry cultivars found them in all the studied plant materials (table 2). It's known that hydroquinone induced generation of reactive oxygen species and quinones leads to the oxidative damage of membrane lipids and proteins such as tyrosinase, and at the same time it inhibits the pigmentation [3]. Due to the risks of side effects hydroquinone has been banned by the European Committee (24 th Dir 2000/6/EC) and formulations have been withdrawn from cosmetics and are available only through prescription. Arbutin (hydroquinone-O- $\beta-d-$ glucopyranoside), a derivative of hydroquinone, is used as an effective treatment of hyperpigmentary disorders, and displays less melanocyte cytotoxicity than hydroquinone [4]. Arbutin inhibits melanogenesis by competitively and reversibly binding tyrosinase without influencing the mRNA transcription of tyrosinase. The use of plant material of the species or varieties with hydroquinone and $\beta$-para-arbutin may be limited in food applications but has a significant advantage in medication.
Most of the identified in V. corymbosum shoots phytochemicals must have antioxidant activity, as has been shown in many species $[6,10]$. Since the production of secondary metabolites in the plant depends not only on the genotype and environmental conditions (the varieties that we studied were grown under the same conditions) but also on the physiological phase of development, Elliott's AOA was studied in the phases of flowering, fruiting, and preparation for winter dormancy. The obtained results indicate a relatively high level of antioxidant activity (table 3 ).

The results showed that $\mathrm{IC}_{50}$ values varied from $1.14 \pm 0.065$ to $2.50 \pm 0.025 \mathrm{mg} / \mathrm{ml}$ depend of the solvent and during flowering; from $1.01 \pm 0.018$ to $2.51 \pm 0.059 \mathrm{mg} / \mathrm{ml}$ during fruiting and from $0.18 \pm 0.016$ to $2.50 \pm 0.087 \mathrm{mg} / \mathrm{ml}$ during preparing for winter dormancy. Since $\mathrm{IC}_{50}$ is inversely associated with anti-radical activity of the extract, the lower the $\mathrm{IC}_{50}$ is the higher is the antioxidant activity. Based on these results, the effect of aqueous-ethanol solvent in concentrations $20,30,40,50,60,70,80$ and $96 \%$ on the AOA was not significant compared to ascorbic acid $(356.36 \pm 6.395 \mu \mathrm{g} / \mathrm{ml})$. Generally, the highest antioxidant activity showed AE extracts in ethanol concentration $40 \%$ during flowering, $80 \%$ during fruiting and $50 \%$ at the beginning of winter dormancy. 
Table 3. $I_{50}$ Vaccinium corymbosum L. (Elliott), $\mathrm{mg} / \mathrm{ml}($ mean \pm SEM, $\mathrm{n}=3$ )

\begin{tabular}{l|c|c|c}
\hline $\begin{array}{c}\text { Samples } \\
\text { (solvent) }\end{array}$ & \multicolumn{3}{|c}{$\mathrm{IC}_{50}$} \\
\cline { 2 - 4 } & $\mathrm{I}$ & $\mathrm{II}$ & $\mathrm{IV}$ \\
\hline $\mathrm{H}_{2} \mathrm{O}$ & $2.50 \pm 0.02$ & $2.51 \pm 0.06^{\#}$ & $2.50 \pm 0.09^{\#}$ \\
\hline $20 \%$ & $1.29 \pm 0.07$ & $1,89 \pm 0.02^{\star *}$ & $1.51 \pm 0.03^{*}$ \\
\hline $30 \%$ & $1.24 \pm 0.05$ & $1.80 \pm 0.04^{\star *}$ & $1.06 \pm 0.06^{\#}$ \\
\hline $40 \%$ & $1.14 \pm 0.06$ & $1.86 \pm 0.03^{\star * *}$ & $1.24 \pm 0.05^{\#}$ \\
\hline $50 \%$ & $1.21 \pm 0.02$ & $2.22 \pm 0.04^{* * *}$ & $0.18 \pm 0.02^{\star \star *}$ \\
\hline $60 \%$ & $1.24 \pm 0.07$ & $1.20 \pm 0.02^{\#}$ & $1.52 \pm 0.11^{\#}$ \\
\hline $70 \%$ & $1.42 \pm 0.02$ & $1.13 \pm 0.03^{* *}$ & $1.13 \pm 0.05^{\star *}$ \\
\hline $80 \%$ & $1.67 \pm 0.03$ & $1.01 \pm 0.02^{* * *}$ & $1.25 \pm 0.02^{\star * *}$ \\
\hline $96 \%$ & $1.89 \pm 0.02$ & $1.23 \pm 0.02^{* * *}$ & $1.47 \pm 0.14^{* *}$ \\
\hline
\end{tabular}

Note. Aqueous ethanol (AE); I, II, IV — stages of flowering, fruiting, preparing for winter dormancy, respectively. ${ }^{\#}-\mathrm{P}>0.05,{ }^{*}-\mathrm{P}<0.05$, ${ }^{* *}-\mathrm{P}<0.01 ; * * *-\mathrm{P}<0.001$.

The phytochemical profiles of plant organs are mainly genetically determined and, thus, are a characteristic of each genus, species, and even variety. Species and varieties of the genus Vaccinium accumulate different groups of substances in their organs and this, in turn, determines the possibilities of their use, in particular for medicinal purposes and as edible. One of the most important components of their extracts is polyphenolic antioxidants. This study confirmed the presence of these groups of compounds in aqueous and ethanol-aqueous extracts from the shoots of $V$. corymbosum. Presented data on the qualitative phytochemical composition of the $V$. corymbosum shoots indicates the presence of a huge variety of phenolic compounds: flavonoids, tannins, phlobatannins. Our previous studies indicate a high content of flavonoids, proanthocyanidins, and tannins in the $\mathrm{V}$. corymbosum shoots [19], as shown in the leaves by other authors $[1,14]$. In this work, it was found that along with flavonoids and derivatives of hydroxycinnamic acids in the shoots of $V$. corymbosum are phenolic compounds of non-flavonoid nature - derivatives of 1,4-dihydroxybenzene - hydroquinone and arbutin, which have antioxidant properties. However, in our opinion, AOA extracts of the studied plants are determined by a wider range of compounds with antiradical properties, as the shoots also contain carotenoids, chlorophylls, ascorbic and organic acids $[18,19]$. Their combined positive effects on human health are discussed in the review [16].

\section{Conclusions}

Extracts of Vaccinium corymbosum shoots (varieties Bluecrop, Bluejay and Elliott) were found to contain different types of primary and secondary metabolites (carbohydrates, reducing sugars, phenols, flavonoids, tannins, phlobatannins, hydroquinone and arbutin) that are involved in important biological activities in humans or animals; aquatic and aqueous ethanol extract possess high antioxidant potential, but lower when compared to reference standard ascorbic acid.

\section{Prospects of Further Research}

The present data will certainly help to establish the effectiveness of the investigated plant materials as a potential source of natural antioxidants for use in nutraceutical and functional foods. However, further research is needed to identify the individual components that form the antioxidant system and their antimicrobial, anti-inflammatory and antidiabetic properties, as well as to develop their applications for the food and pharmaceutical industries.

1. Contreras RA, Köhler H, Pizarro M, Zúiga GE. In vitro cultivars of Vaccinium corymbosum L. (Ericaceae) are a source of antioxidant phenolics. Antioxidants. 2015; 4 (2): 281-292. DOI: 10.3390/ antiox4020281.

2. Del Rio D, Rodriguez-Mateos A, Spencer JPE, Tognolini M, Borges G, Crozier A. Dietary (poly)phenolics in human health: structure, bioavailability, and evidence of protective effects against chronic diseases. Antioxid. Redox Signal. 2012; 18 (14): 1818-1892. DOI: 10.1089/ars.2012.4581.

3. Draelos ZD. Skin lightening preparations and the hydroquinone controversy. Dermatol. Ther. 2007; 20 (5): 308-313. DOI: 10.1111/ j.1529-8019.2007.00144.x.

4. Ebanks JP, Wickett RR, Boissy RE. Mechanisms regulating skin pigmentation: the rise and fall of complexion coloration. Int. J. Mol. Sci. 2009; 10 (9): 4066-4087. DOI: 10.3390/ijms10094066.

5. Gurlyov DS. Handbook of photography (processing of photographic materials). Kyiv, Tekhnika, 1988: 335 p. (in Russian)

6. Krishnaiah D, Sarbatly R, Nithyanandam R. A review of the antioxidant potential of medicinal plant species. Food and Bioproducts Processing. 2011; 89 (3): 217-233. DOI: 10.1016/j.fbp.2010.04.008.

7. MSU Extension. Blueberries: Growth Stages. Michigan State University. Available at: https://www.canr.msu.edu/blueberries/ growing_blueberries/growth-stages

8. Noorul H, Mujahid M, Badruddeen, Khalid M, Vartika S, Nesar A, Zafar K, Zohrameena S. Physico-phytochemical analysis and estimation of total phenolic, flavonoids and proanthocyanidin content of Persea Americana (avocado) seed extracts. World J. Pharm. Sci. 2017; 5 (4): 70-77. Available at: http://www.wjpsonline.org/ admin/uploads/HMqFIW.pdf

9. Rauf A, Uddin G, Ali M, Ahmad N, Gul S. Phytochemical screening and antioxidant activity of Pakistani medicinal plants. Wudpecker J. Med. Plants. 2013; 2 (1): 001-006. Available at: https://www.researchgate.net/publication/236512561

10. Shahidi F, Ambigaipalan P. Phenolics and polyphenolics in food, beverages and spices: antioxidant activity and health effects - a review. J. Func. Foods. 2015; 18 (B): 820-897. DOI: 10.1016/j.jff.2015.06.018.

11. State Pharmacopoeia of Ukraine. State Enterprise "Ukrainian Medicines". $1^{\text {st }}$ type. Appendix 4. Kharkiv, Ukrainian Scientific Pharmacopoeial Center for Quality of Medicines, 2011: 540 p. (in Ukrainian)

12. State Pharmacopoeia of Ukraine. State Enterprise "Ukrainian Scientific Pharmacopoeial Center for Drug Quality". $2^{\text {nd }}$ ed, vol. 1. Kharkiv, Ukrainian Scientific Pharmacopoeial Center for Drug Quality, 2015: 1110 p. (in Ukrainian)

13. State Pharmacopoeia of the USSR: Vol. 2. General methods of analysis. Medicinal plant raw materials. Ministry of Health of the USSR. 11 ${ }^{\text {th }}$ ed., Ext. Moscow, Medytsyna, 1989: 400 p. (in Russian)

14. Ștefănescu BE, Szabo K, Mocan A, Crişan G. Phenolic compounds from five ericaceae species leaves and their related bioavailability and health benefits. Molecules. 2019; 24 (11): 2046. DOI: 10.3390/molecules24112046.

15. Tressera-Rimbau A, Arranz S, Eder M, Vallverdú-Queralt A. Dietary polyphenols in the prevention of stroke. new insights into the benefits of polyphenols in chronic diseases. Ox. Med. Cell. Longevity. New Insights into the Benefits of Polyphenols in Chronic Diseases. 2017; Article ID 7467962. DOI: 10.1155/2017/7467962. 
16. Visioli F, De La Lastra CA, Andres-Lacueva C, Aviram M, Calhau C, Cassano A, D'Archivio M, Faria A, Favé G, Fogliano V, Llorach R, Vitaglione P, Zoratti M, Edeas M. Polyphenols and human health: a prospectus. Critical Rev. Food Sci. Nutr. 2011; 51 (6): 524-546. DOI: 10.1080/10408391003698677.

17. Yavorska N, Vorobets N. Phytosynthetic pigments in shoots of Vaccinium corymbosum L. (Cv. Elliott). Agrobiodiversity for Improving Nutrition, Health and Life Quality. 2019; 3: 93-100. DOI: 10.15414/agrobiodiversity.2019.2585-8246.093-100.
18. Yavorska NY, Vorobets NM. Seasonal variation in the ascorbic and organic acids content in shoots of highbush blueberry cultivars during vegetation stages. Med. Clin. Chem. 2020; 22 (2): 31-38. DOI: 10.11603/mcch.2410-681X.2020.v.i2.11355. (in Ukrainian)

19. Yavorska NY, Vorobets NM. Seasonal variation in the polyphenol and flavonoids content in shoots of highbush blueberry cultivars during vegetation stages. Bulletin of Problems of Biology and Medicine. 2020; 3 (157): 71-75. DOI: 10.29254/20774214-2020-3-157-70-75. (in Ukrainian)

\title{
Попередній порівняльний фітохімічний скринінг і антиоксидантна активність екстрактів пагонів різних сортів Vaccinium corymbosum L. (Ericaceae)
}

\author{
Н. Я. Яворська ${ }^{1}$, Н. М. Воробець', Ю. Т. Салига², О. І. Вішур² \\ vishchur_oleg@ukr.net \\ 1Львівський національний медичний університет ім. Данила Галицького, \\ вул. Пекарська, 69, м. Львів, 79010, Україна \\ ${ }^{2}$ Інститут біології тварин НААН, \\ вул. В. Стуса, 38, м. Львів, 79034, Україна
}

Сорти Vaccinium corymbosum L. (Ericaceae) широко відомі у різних регіонах всіх континентів з відповідним кліматом. До нині переважно використовували плоди цих рослин, решту — вегетативну надземну частину, яка залишалась під час обрізання кущів не застосовували. Тим часом пагони інших видів Егісасеае здавна використовують як сировину для потреб фрармації, медицини та ветеринарії. Ми використали методи біохімічного скринінгу для виявлення різних груп фітохімічних речовин у пагонах трьох сортів V. corymbosum, інтродукованих в Україні, за допомогою якісних хімічних тестів, щоб дати загальне уявлення про природу компонентів, присутніх в рослинному матеріалі, особливо з антиоксидантною активністю. Крім того, визначено вміст екстрактивних речовин в отриманих екстрактах на різних стадіях розвитку рослин і їхню антиоксидантну активність з використанням методу уловлювання радикалів з DPPH. Фітохімічний скринінг екстрактів пагонів трьох сортів V. corymbosum (Bluejay, Bluecrop, Elliott) показав наявність вуглеводів, редукуючих цукрів, фенолів, фрлавоноїдів, танінів, фрлобатаннінів, гідрохінону і арбутину, які проявляють антиоксидантні властивості; вміст екстрактивних речовин залежить від розчинника і стадії розвитку рослини. У водних витяжках Bluejay найбільшу кількість екстрактивних речовин спостерігали у період цвітіння і на початку зимового періоду; y Bluecrop - під час плодоношення і на початку зимового періоду; а у Elliott — на початку зимового періоду. Таким чином, можна стверджувати про перспективність вивчення у пагонів V. corymbosum антимікробних, протизапальних, антидіабетичних властивостей, а також можливостей їх застосування як кормової добавки до корму для тварин.

Ключові слова: Vaccinium corymbosum, екстрактивні речовини, скринінг розчинних сполук, антиоксидантна активність

Yavorska NY, Vorobets NM, Salyha YT, Vishchur OI. Preliminary comparative phytochemical screening and antioxidant activity of varieties V. corymbosum shoot' extracts. Biol. Tvarin. 2020; 22 (4): 3-8. DOI: 10.15407/animbiol22.04.003. 